\title{
11. Institutional and Regional Factors Behind University Patenting in Europe: An Exploratory Spatial Analysis Using EUMIDA Data
}

\author{
Attila Varga - Márton Horváth ${ }^{1}$
}

\begin{abstract}
Over the past 30 years universities have been increasingly considered as key instruments of regional economic development policy in many countries of the World. Contrary to the US where studying the entire universe of academic institutions is a real possibility thanks to the availability of regularly collected nation-wide information on all universities in Europe no such coordinated data collection efforts are in existence. This is why the EUMIDA database constitutes such a pioneering work. In this paper we take advantage of the availability of the EUMIDA data for scientific investigations.

We selected to focus on one specific, widely promoted form of academic entrepreneurship: university patenting. Following what the literature teaches us about the likely institutional and regional level impacts on academic entrepreneurship we utilize EUMIDA information to build as large a sample as possible to study European-wide tendencies of university patenting. Regional level impacts are investigated at the NUTS 3 level, which is in itself a novelty in the literature. This lower level of data aggregation opens the possibility to get closer to the spatial level of metropolitan areas where university-industry interactions most probably take place.
\end{abstract}

Keywords: EUMIDA, university patents, regional knowledge production function, European regions

\section{Introduction}

Over the past 30 years universities have been increasingly considered as key instruments of regional economic development policy in many countries of the World (Pike et al. 2011). High expectations towards positive regional economic impacts of academic institutions are partly supported by the experience of some leading technology areas where knowledge transfers from universities successfully nurtured regional economic growth (Saxenian 1994, Wicksteed et al. 2000, Goldstein 2002) and partly by research findings in the scientific literature providing strong empirical evidence as to the important role of spatial proximity of firms to academic institutions in knowledge transfers (Varga 1998).

It became clear for researchers of the field relatively soon that a pure proximity of a university is not a guarantee for growth as regional and university level characteristics are both instrumental in determining the extent to which university-supported economic development might be considered as a realistic option for a region. Without some preconditions in the locality even a world-class research university might exert only

\footnotetext{
${ }^{1}$ The research underlying this study was supported by the MTA-PTE Innovation and Economic Growth research group (14121) project.
} 
negligible impacts on the local economy (Feldman 1994). The literature shows that below a certain threshold of agglomeration of the local knowledge industry (including innovative firms, private research labs, business services, supporting institutions) hopes for a significant university impact are more or less non-realistic as indicated by US (Varga 2000, Koo 2007) and European (Varga et al. 2012) investigations. In the absence of absorptive capacities in the region research conducted at its universities might be the source of growth in other territories where the local innovation environment have already been satisfactorily developed (AzagraCaro et al. 2013).

Studies focusing on specific mechanisms of academic knowledge transfers provide additional information on those regional and institution-level characteristics that might be instrumental in university-supported regional growth. Knowledge flows from universities to the local industry can take various forms ranging from regional mobility of university graduates and joint research with industry to informal knowledge spillovers between academic and industrial scientists (Varga 2009). One specific channel of academic knowledge transfers frequently called "academic entrepreneurship" attracts an especially intense attention of researchers and policymakers alike. Academic entrepreneurial activities include disclosing, patenting or licensing economically useful new technological knowledge developed by university faculty, spinning-off a firm from academic laboratory research or professional consulting offered by scientists working at academia (Louis et al. 1989, Gulbrandsen Slipersaeter 2007).

Some of the academic entrepreneurship studies bring further evidence on the importance of the regional environment for academic technology transfers. Based on the sample of 404 companies from 64 Italian universities Fine and his co-authors (2011) conclude that innovative performance of the region as well as the size of its public $R \& D$ expenditures, or the presence of regional support institutions (such as incubators) significantly influence university spin-off firm formation. According to the study by Saragossi and Van Pottelsberghe de la Potterie (2003) patenting at Belgian universities is supported by the presence of collaborating institutions in the region specializing in the same field of research. Additionally, Siegel and his co-authors (2003) report that their 98 interviews at five research universities suggest that there is a positive association between $R \& D$ conducted by local firms and the productivity of technology transfer from the universities. However, the regional impact does not always get evidenced such as in Acosta and his co-authors (2011) where the extent of university patenting in Europe does not appear to be influenced by regional factors. 
Academic entrepreneurship studies also reveal that certain characteristics of universities may influence knowledge transfers from academia. Research intensity of universities affects the effectiveness of university technology transfer offices (TTO) positively in the sample of 131 US universities (Rogers et al. 2000). Positive effects of university research intensity are found on patenting (Coupé 2003) and licensing (Lach - Shankerman 2003) for samples of US universities and for the University of Valencia (Azagra-Caro et al. 2003). University size impact on the extent of academic technology transfers varies by scientific areas for a sample of 4000 Canadian university researchers in Landry and co-authors (2007) and for TTO effectiveness with a sample of 170 US universities in Carlsson and Fridh (2002). The size effect is also found prevalent for the number of licenses and the amount of royalty income for a sample of 90 US universities (Friedman - Silberman 2003) and for different types of university-industry linkages at Austrian universities (Schartinger et al. 2002) and in two wine clusters (Giuliani - Arza 2009).

Third party research funding from governmental and private sources is positively related to license income in Lach and Shankerman (2003) and to the intensity of scienceindustry relations on the basis of a survey of 4900 researchers in Ponomariov (2007). Licensing (Friedman and Silberman 2003, Lach and Shankerman 2003), university-industry linkages (Guiliani - Arza 2009, Ponomariov 2007) and faculty entrepreneurial performance at the Catholic University of Leuven (Van Looy et al. 2004) are also positively associated with faculty quality. TTOs don't seem to matter in faculty spin-offs for a sample of biotechnology firms in Hungary (Erdős - Varga 2012), but the quality of TTOs found to be positively associated with TTO productivity when a sample of 55 academic entrepreneurs are interviewed by Siegel and his co-authors (2003) and when 131 US universities are surveyed in Rogers et al. (2000). Furthermore, positive impacts of university prestige on entrepreneurial performance (Van Looy et al. 2004), of scientific specialization on technology transfer intensity (Landry et al. 2007) and of a supportive departmental environment on patenting (Renault 2006) and spin-offs (Erdős - Varga 2012) are reported in the literature.

Thus the literature suggests that individual university characteristics and regional features explain much of the observed differences in academic entrepreneurship. However, most of the studies referred above are based on relatively small samples of universities. This is less true for some of the US investigations where studying the entire universe of academic institutions is a real possibility because of the existence of data collected nationally on a regular basis such as the licensing surveys of the Association of University Technology Managers (AUTM 2011) or the WebCASPAR database maintained by the National Science 
Foundation (NSF 2010). However for European universities no such coordinated EU-wide data collection efforts are in existence. This is why constructing the EUMIDA database constitutes such a pioneering work (Bonaccorsi et al. 2010).

In our study we take advantage of the availability of the EUMIDA data for scientific investigations. We selected to focus on one specific, widely promoted form of academic entrepreneurship: university patenting. Following what the literature teaches us about the likely institutional and regional level impacts on academic entrepreneurship we utilize EUMIDA information to build as large a sample as possible to study European-wide tendencies of university patenting. Regional level impacts are investigated at the NUTS 3 level, which is in itself a novelty in the literature. This lower level of data aggregation opens the possibility to get closer to the spatial level of metropolitan areas where university-industry interactions most probably take place (Varga 1998). The second section introduces the development of the novel regional EUMIDA data and then provides an exploratory analysis on institutional and regional factors behind university patenting. The third section follows the results of an econometric analysis. Summary concludes our chapter.

\section{University patents, institutional and regional factors: A descriptive analysis}

The EUMIDA project is a major step towards the development of a system of integrated European-wide data collection on higher education institutions (Bonaccorsi et al. 2010). EUMIDA data sets reflect what is currently available as a result of individual national data compilation efforts. Identification of the respective NUTS 3 regions for each EUMIDA institution required substantial efforts since the original national data tables do not contain the appropriate regional breakdown at the level of institutions (Bonaccorsi et al. 2010). In the followings we shortly summarize the major steps in the regionalization of the EUMIDA data.

Identification of each academic institution, their cities and then the determination of the corresponding NUTS 3 regions turned out to be extremely challenging. A series of systematic Internet-based searches appeared to be the most efficient data collection method. When institution names in the corresponding languages remained unchanged since the time of EUMIDA data collection a Google search appeared satisfactory for the identification of the university. However, when names of those institutions, which were subject to integration or separation had changed individually specified search methods were followed (e.g., detailed investigations on the existing institutions' home pages or data collections in Wikipedia) in 
identifying the original institution. Once the original institutions were found on the Internet the next step was to determine the corresponding city names from the web pages.

Contrary to what is the case for example in the United States where a correspondence table with ZIP codes, city and county names are available there is no uniform correspondence between municipalities and regions in Europe. To earn this information on EUMIDA institutions' campuses we used mainly the following correspondence databases provided by Eurostat:

1. The system of Local Administrative Units (LAU) that contains correspondence between LAU and NUTS 3 codes. This correspondence was useful in the cases of those countries where the LAU 2 level coincides with municipalities and the names appear the same $^{2}$.

2. Eurostat provides a concordance between local postcodes, localities and NUTS regions in a special database (the "Postcodes and Nuts" database) that contains more alternatives of the locality names ${ }^{3}$.

3. 3The case of the United Kingdom generated the most complicated identification processes. In this country LAU regions do not overlap with the boundaries of municipalities (and the names of these regions also do not refer to municipalities) and UK postcodes are not in the Eurostat "Postcodes and Nuts" database. We used the ArcGIS Explorer and Google Maps to localize the municipalities and the shape files of NUTS 3 boundary maps to determine the region of municipalities.

As the EUMIDA Final Study Report points it out (Bonaccorsi et al. 2010) no information is available on how institutional resources of a university are allocated to different campuses though it is obvious that a significant number of universities are multisited. Without a more appropriate solution we allocated university resources to the NUTS 3 regions where the municipality of the main seats of the institutions are located. In the case of multi-site universities (approximately 5 percent of the institutions) always the first address (city) was chosen or the one where the administrative center of the institution is located. With

\footnotetext{
${ }^{2}$ LAU-NUTS3 correspondence tables were usable in the following countries: AT, BE, BG, CY, CZ, DE, EE, ES, FI, GR, HU, IT, LU, LV, MT, NL, PL, RO, SE, SI, SK.

3 "Correspondence tables: Postcodes and NUTS":

http://epp.eurostat.ec.europa.eu/portal/page/portal/nuts_nomenclature/correspondence_tables/postcodes_and_nuts
} 
this method, we ended up with a one to one correspondence of universities and NUTS 3 regions ${ }^{4}$.

Out of the universe of approximately 2900 higher education institutions in Europe the Core EUMIDA data set contains 2457 institutions, which covers 27 European nations. Because of insufficient data availability France and Denmark are not part of the Core data set. Resulting from a further data collection effort the Extended EUMIDA data set provides broader information but only for a select set of institutions, mainly for those with research orientation. Table 1 indicates that almost all of the research active (1360 out of 1405), doctoral degree granting (846 out of 886) and public (1071 out of 1380) universities in the Core EUMIDA data set are covered in the Extended data set. Provided that scientific quality correlates with the probability of patenting (Renault 2006) our investigations of the impacts of institutional and regional factors on university patenting are built on information provided in the Extended EUMIDA data set.

Following the related literature summarized in the Introduction and considering the availability of information in the Extended EUMIDA data set university-level characteristics to be accounted for in the analysis of university patenting are as follows:

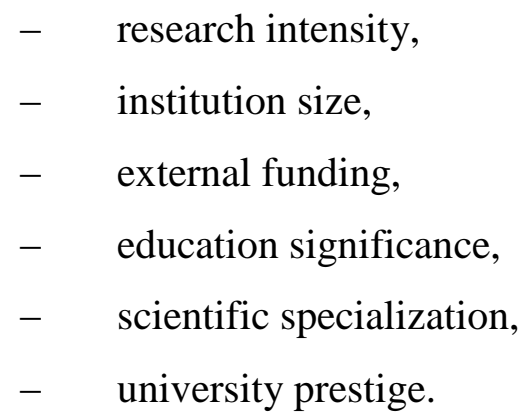

To control for knowledge accessed by university researchers from the international research community we test for the likely impact of international embeddedness. Age of the institution and education significance are added as further control characteristics.

\footnotetext{
${ }^{4}$ Even following the above-described methodology very carefully we still cannot ignore potential shortcomings in the resulting regionalized data. Reliability of the data is not balanced because we do not have knowledge about the extent to which information published on web pages of institutions is indeed relevant. In most of the cases it was obvious that the addresses of the institutions were correct. However, in some other cases we realized and tried to correct the apparent mistakes by for example further browsing on the pages. Also it is not easy to assess the reliability of the information earned from those web sites or online applications that contain information uploaded by users (e.g. Wikipedia, Google Maps). To restrict the level of risk, we insisted to use at least two Internet sources in every case to control for mistakes.
} 
Table 1 Number of universities in the Core and the Extended data sets for selected variables

\begin{tabular}{|c|c|c|}
\hline & Core data set & Extended data set \\
\hline \multicolumn{3}{|l|}{ RESEARCH ACTIVITY } \\
\hline No & 1015 & 3 \\
\hline Yes & 1405 & 1361 \\
\hline No information & 37 & \\
\hline \multicolumn{3}{|l|}{ HIGHEST DEGREE AWARDED } \\
\hline Bachelor & 787 & 219 \\
\hline Diploma & 59 & 6 \\
\hline Doctorate & 886 & 846 \\
\hline Intermediary ISCED 6 qualification & 5 & 5 \\
\hline Master & 136 & \\
\hline Master or pre-Bologna equivalent & 538 & 277 \\
\hline No information & 46 & 11 \\
\hline \multicolumn{3}{|l|}{ LEGAL STATUS } \\
\hline Government dependent & 138 & 99 \\
\hline Private & 933 & 193 \\
\hline Public & 1380 & 1071 \\
\hline No information & 6 & 1 \\
\hline Sum & 2457 & 1364 \\
\hline
\end{tabular}

Source: authors' own construction

On the base of the literature search the following regional characteristics of university patenting were selected for analysis:

- $\quad$ regional size (to control for agglomeration effects),

- regional university research intensity (to control for the potential impact of the concentration of public research in the region),

- industrial specialization (to control for potential university-industry interactions in technology development),

- $\quad$ regional innovation (to control for the innovativeness of the region).

Appendix tables A1 and A2 list all the variables from EUMIDA and additional data sources that could potentially serve as proxies of the above listed institutional and regional level characteristics. While selecting a particular variable to proxy any of the characteristics we followed three criteria. The first one is related to the size of the sample. Unfortunately, for most of the variables in the Extended EUMIDA data set values for many institutions are not 
reported. As a consequence, for some of the variables the number of available observations became so low that it seriously jeopardizes representativeness. Figure 1 provides two examples for the bias caused by the low level of observations: overrepresentation of the UK and Hungary in the R\&D expenditures variable (Figure 1a) and of Germany, the UK and some additional countries in the Foreign academic staff variable (Figure 1b).

Figure 1 Problems with representativeness in the Extended data set. Two examples: R\&D expenditures and foreign academic staff

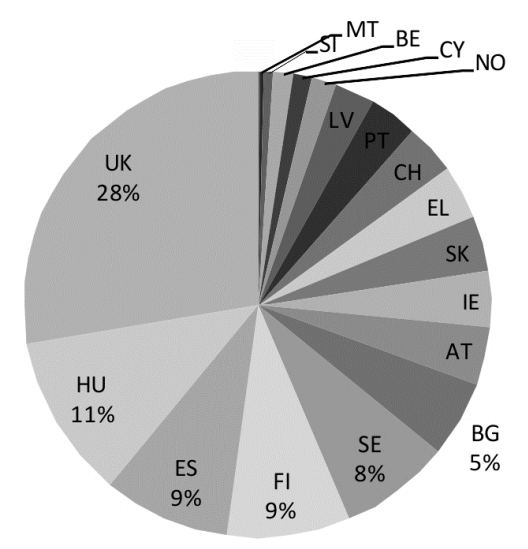

Figure 1a: R\&D Expenditures in EUR (535 institutions)

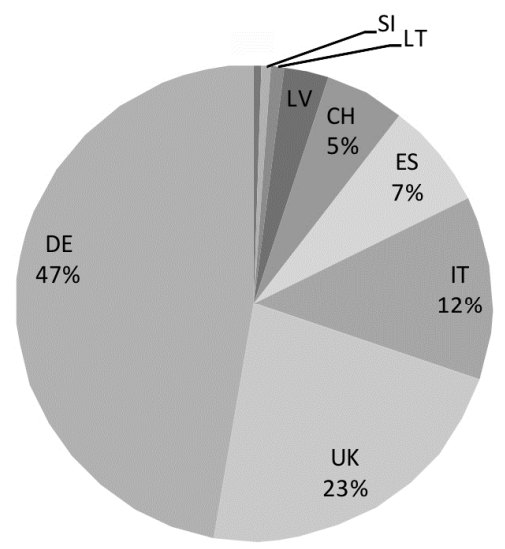

Figure 1b: Foreign academic staff (647 institutions)

Source: authors' own construction

Additional to ensuring sufficient levels of representativeness by systematically searching for variables with the highest possible number of observations the second criterion was related to explanatory power. In Appendix tables A1 and A2 the main statistics of the regressions are presented. Parameter significances and regression fits advise as to which variable to select. The third criterion was associated with a systematic regression analysis presented in the following section (Tables 3 and 4). As indicated there for some of the characteristics each potential variable was included in the regression model one by one separately. Those variables that were selected for analysis showed the best properties with respect to regression fit and parameter significance.

Descriptive statistics of the selected variables are shown in Table 2. In general the spread of values are considerably high. While means are low, standard deviations in some cases are several times higher. Therefore most of the observations have values close to the respective minimums while some of the universities take outstanding values for all variables. We measure university patenting by the number of patents assigned to academic institutions 
in the years $2006-2008^{5}$. Data come from the PATSTAT database maintained by the OECD ${ }^{6}$. The examined 1364 institutions have 823 patents altogether. Average number of patents per institution does not reach the value of one, but the high maximum value indicates the existence of some universities with intensive patenting activity. Number of doctoral degrees awarded is our proxy for research activity.

Table 2 Descriptive statistics of the selected variables

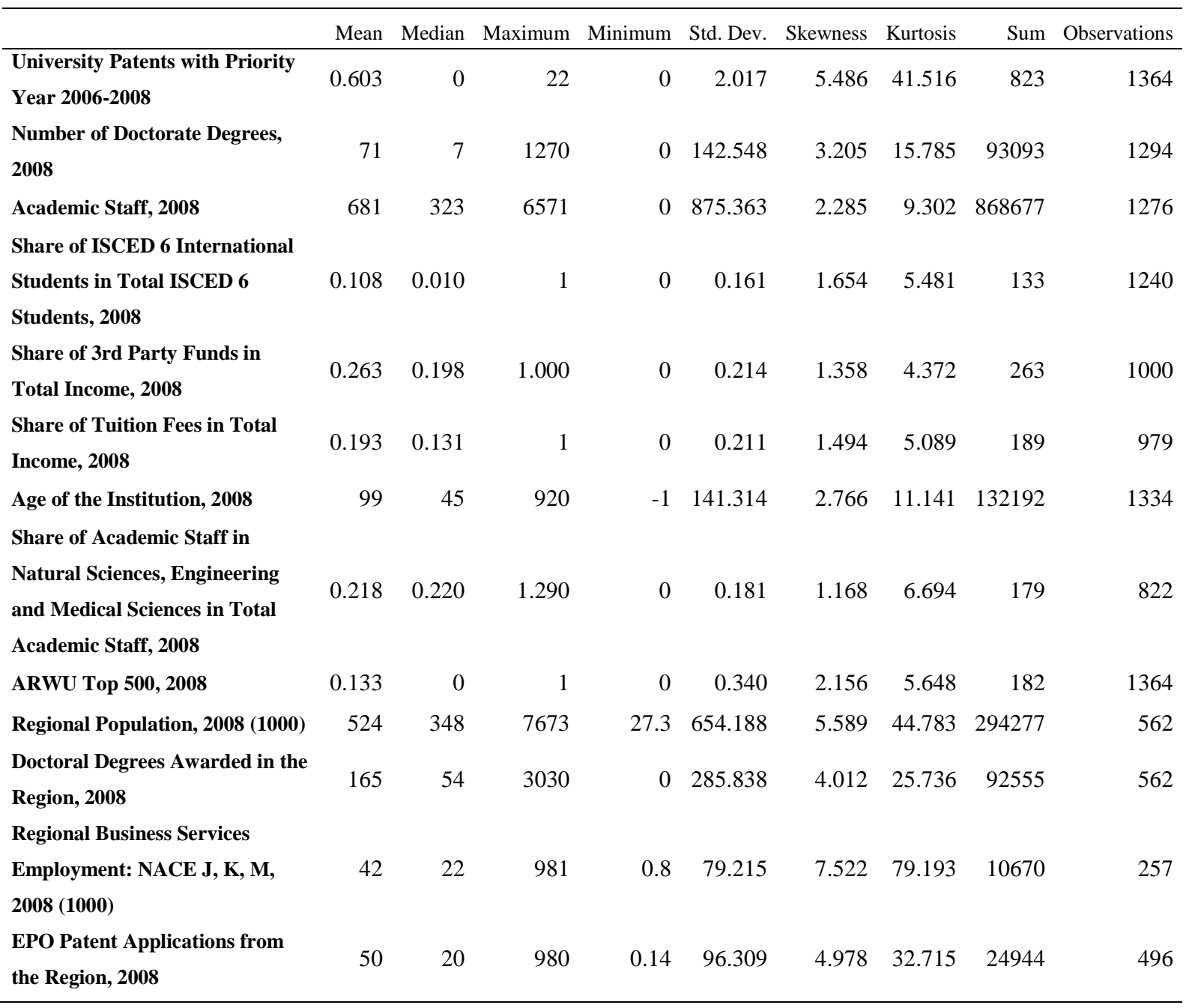

Source: authors' own construction

\footnotetext{
${ }^{5}$ At the time of data collection (Spring 2012) it was clear that beginning with 2008 the number of university patents showed a drastic decline for each institution. A well-known technical reason is that considerable time is required by the European Patent Office to examine and decide on all claims they receive. Thus we were not able to follow the widely applied solution in patent studies (i.e., application of at least a two-year lag between the date of patent application and the date of $R \& D$ expenditures). Since the spatial pattern of both the inputs of knowledge production (such as R\&D) and patenting show a remarkable stability over a time span of about 3 to 5 years (Varga et al. 2005) and many of the low-patenting academic institutes do not submit claims in each year we found our choice of summing up the number of patents over the period of 2006-2008 for each university satisfactorily for our exploratory analysis.

${ }^{6}$ The specific data we use were presented by "Knowledge, Internationalization and Technology Studies" at Bocconi University, Milan, Italy.
} 
Its distribution is similar to that of university patents: the average value per an institution is 71 and most of the universities exhibit relatively small values while outstanding institutions award several hundred degrees a year. University size represented by academic staff shows a similar distribution. To proxy an institution's international embeddedness we decided to apply the variable Share of ISCED 6 International Students in Total ISCED 6 Students (master and $\mathrm{PhD}$ ). The ratio of ISCED 6 student in the respective total adds up to 10 percent of total students on average but the distribution around the mean is also highly uneven.

Average share of third party funds (our measure for external funding) and tuition fees (measuring the significance of education) are 26.3 and 19.3 percentages, respectively. However, the distribution of these variables in the sample is more even than those variables described above. Academic staff in natural sciences, engineering and medical sciences is expected to be the most active in university patenting. Interestingly, many of the universities exhibit a value of this variable somewhere around the sample mean. 182 institutions (13.3\%) were ranked in the Top 500 according to the Academic Rankings of World Universities in 2008 .

Universities in the extended data set are located in 562 NUTS 3 regions. These regions are quite heterogeneous. The average number of inhabitants is 524 thousand people but the vast majority of them are less populated while the most agglomerated territories measure up to millions of people. There is a high variation in the regionally aggregated number of doctoral degrees awarded in 2008 (our measure for regional university research intensity). Eurostat provides information on employment structure by industries only for 257 regions out of the selected 562. Regional business services employment (the choice for local industry specialization) shows high interregional volatility since its concentration is more intense than that of population. Regional technological output proxied by EPO patent applications in 2008 is also highly concentrated in space with the mean of 50 applications and a standard deviation almost doubling the mean.

Thus both institutional and regional variables are highly concentrated in space with considerable right-side skewness. Therefore for many of the variables most of the observations take relatively low values while a small number of them exhibit outstanding values. Histograms in Figure 2 clearly show that several variables follow a power-law distribution. Number of university patents and doctoral degrees awarded are concentrated most intensely. Less concentrated values characterize variables such as academic staff and the share of ISCED 6 international students. On the other hand the distribution of third party funding, the share of tuition fees in income and scientific specialization of universities are more balanced. 
Figure 2 University patents and the main institutional variables: histograms

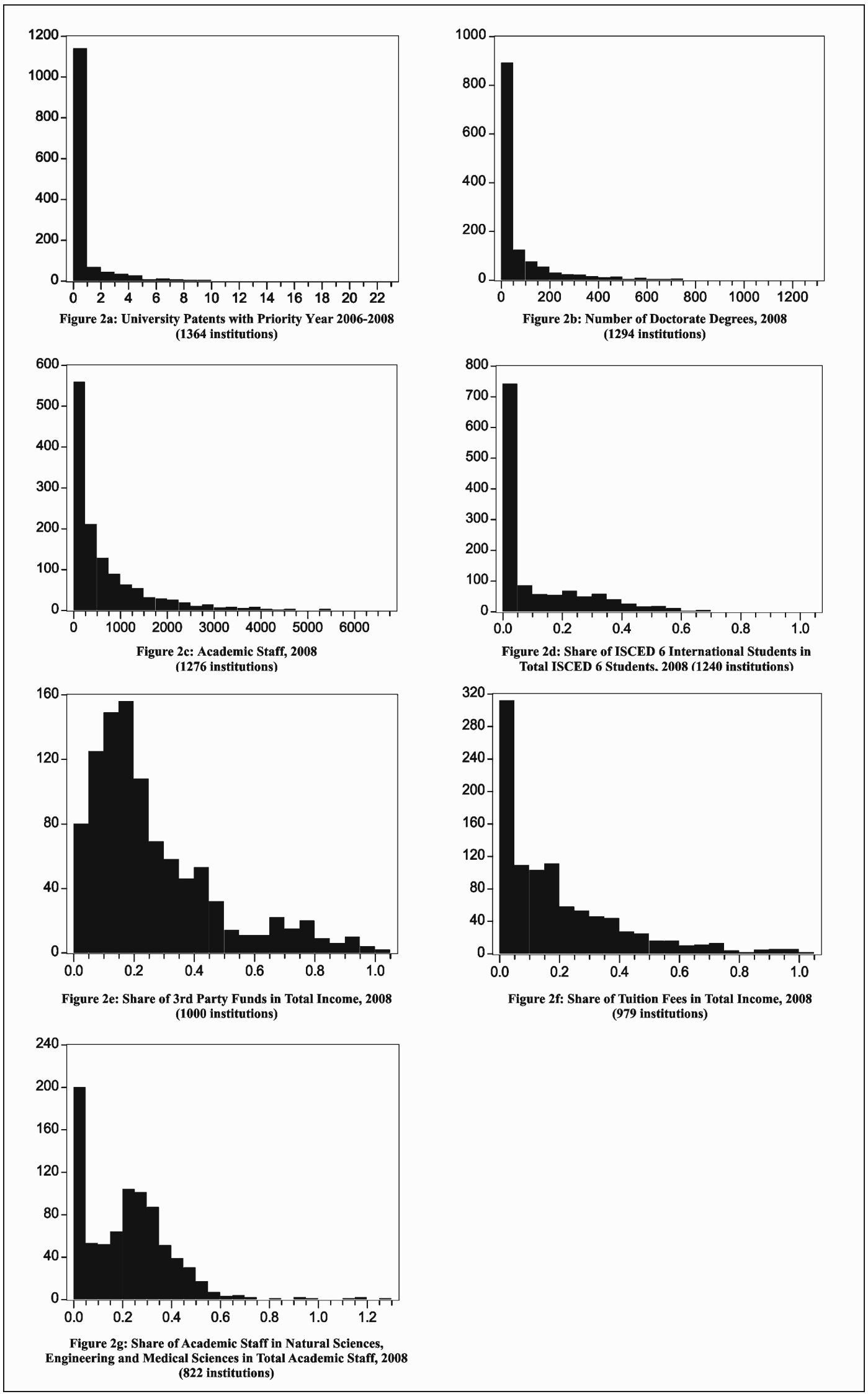

Source: authors' own construction 
Pairwaise correlations of univrsity patents and the selected variables are depicted in Table 3. The table provides correlation statistics both for the full sample and for the sample without the outlier values. Outliers are defined here as observed values exceeding the sample mean with more than two standard deviations.

Table 3 Correlations between university patents and variables of university and regional characteristics for all observation and without outliers

\begin{tabular}{lrr}
\hline Variable name & All observations* & $\begin{array}{r}\text { Without } \\
\text { outliers** }\end{array}$ \\
\hline Academic Staff, 2008 & 0.578 & 0.420 \\
Number of Doctoral Degrees, 2008 & 0.550 & 0.376 \\
Share of ISCED 6 International Students in Total ISCED 6 Students, & 0.303 \\
2008 & 0.369 & 0.093 \\
Share of 3rd Party Funds in Total Income, 2008 & 0.114 & -0.127 \\
Share of Tuition Fees in Total Income, 2008 & -0.127 & 0.194 \\
Age of the Institution, 2008 & 0.332 & 0.217 \\
Share of Academic Staff in Natural Sciences, Engineering and Medical & & 0.405 \\
Sciences in Total Academic Staff, 2008 & 0.237 & 0.000 \\
ARWU Top 500, 2008 & 0.525 & 0.017 \\
Regional Population, 2008 (1000) & 0.106 & -0.006 \\
Doctoral Degrees Awarded in the Region, 2008 & 0.090 & -0.023 \\
Regional Business Services Employment: NACE J, K, M, 2008 (1000) & 0.004 \\
EPO Patent Applications from the Region, 2008 & & 0.060 \\
\hline
\end{tabular}

Source: authors' own construction

Note: *All observations available pair wise, **Observations available pair wise without those has higher values than the mean plus two times the standard deviation

The strongest relations (correlations between 0.5 and 0.6 ) are found for university size, research activity and university prestige. Scatterplots in Figure 3 and 4 provide series of twodimensional coordinate systems to depict the values of university patents and institutional or regional characteristics pairwise. The plains are divided by a vertical (institutional or regional characteristics) and a horizontal (university patents) lines standing for the values of the mean plus two standard deviations. Therefore observations above the horizontal line and right from the vertical one are considered as outliers. In each figure the majority of institutions fall into the lower left quadrant. Outliers demonstrate a visible positive impact on patenting which is also represented by the respective correlation values in Table 3. 
Figure 3 University patents and the main institutional variables: scatterplots

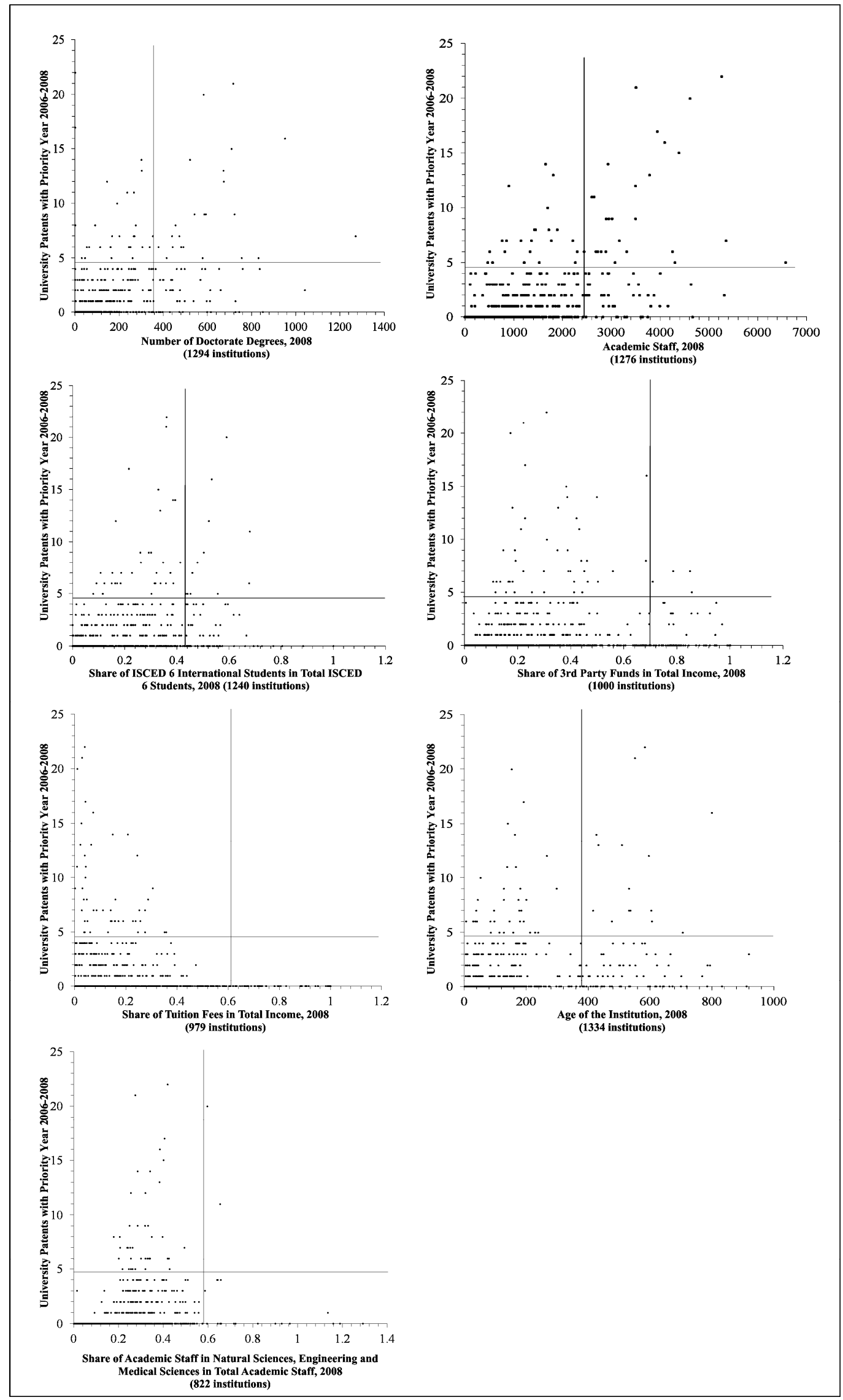

Source: authors' own construction 
Figure 4 University patents and the main regional variables: scatterplots

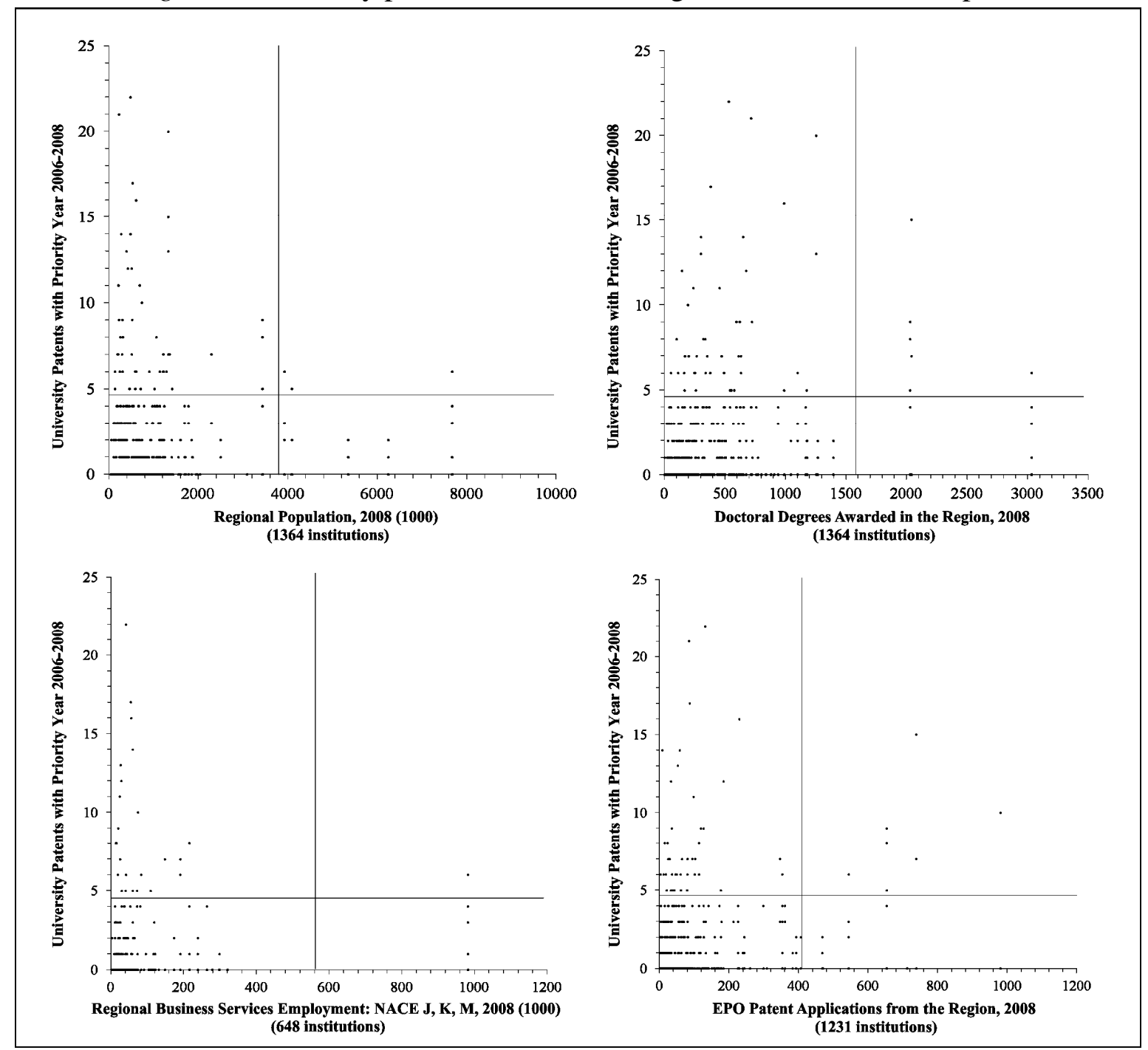

Source: authors' own construction

International embeddedness, the age of institutions and scientific specialization are less correlated with patenting and less increased by the inclusion of outliers. The share of third party funds and tuition fees in income seem to be almost ineffective in patenting what possibly reflects that perhaps all universities (and not only the outliers) have to place these resources in their income portfolio. This observation might also suggest that increased market-oriented education might have an adverse impact on research focus. Correlations with regional indicators seem to have no impact on university patenting. However even these correlations seem to increase slightly by the inclusion of high patenting institutions in special regional environments. However, the general picture is that on average there is no observed spatial coincidence between university patenting and regional features. 
Figure 5 The spatial distributions of university patents and the main institutional variables

(EU NUTS 3 level)

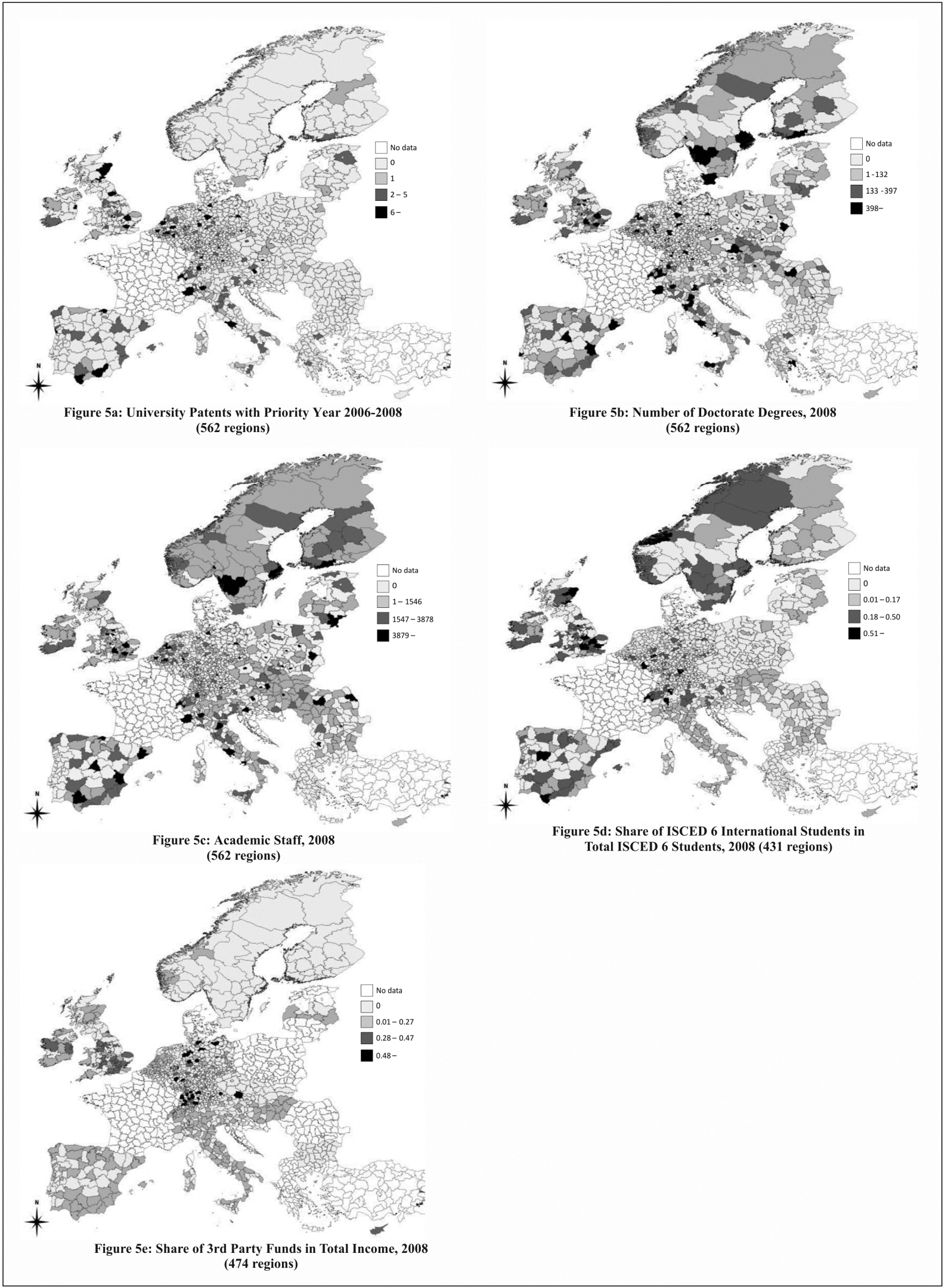

Source: authors' own construction 
Figure 6 The spatial distributions of university patents and the main regional variables (EU NUTS 3 level)

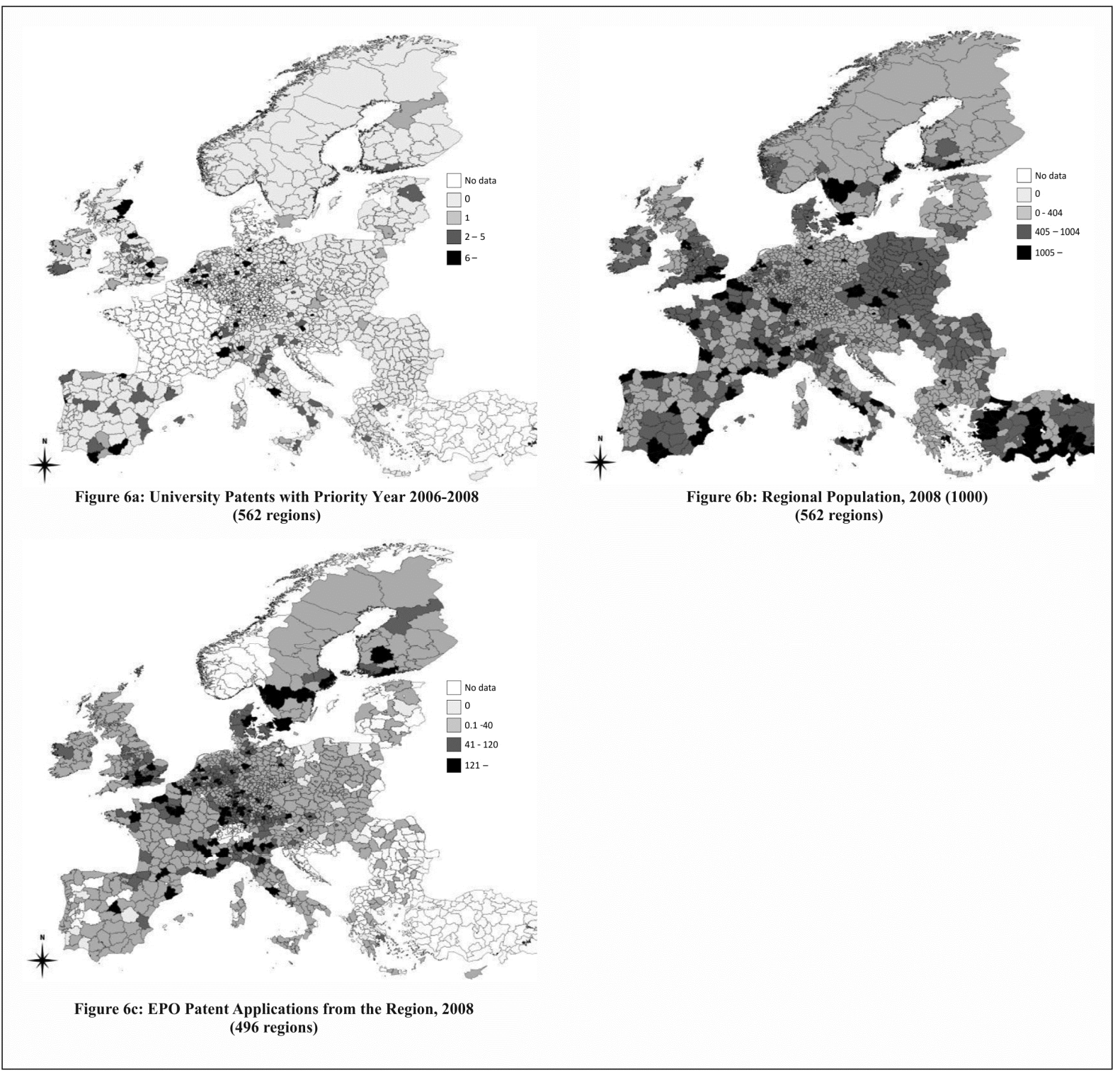

Source: authors' own construction

Figures 5 and 6 map the spatial distribution of university patents and institutional/regional factors in Europe. Institutions of the Extended data set are located in 562 NUTS 3 regions but patenting concentrate in 180 regions. However, outstanding patent owner universities (with 5 or more patents) are located only in 53 regions, mainly in Germany and the UK and in some regions in Italy, the Netherlands, Belgium, Switzerland, Spain and Austria, Portugal and Ireland. Most patenting regions are frequently large agglomerations or capital areas. Research activity is more dispersed in space but the highest values are located also in agglomerations. The spatial pattern of academic staff (representing university size) appears similar to that of research intensity. It is quite interesting that values of the variable proxying international 
embeddedness are concentrated only in some of the countries (United Kingdom, Switzerland, Scandinavian countries and some Italian, German and Spanish regions).

Reliance on third party funds seems to be mainly a German phenomenon but they also form substantial shares in the incomes of some British, Italian, Swiss, Dutch and Belgian regions too. In Figure 6 regional population follows a pattern close to that of university size and research activity. Regional innovative output (measured by patent applications) seems to be geometrically concentrated around the center of Europe and the most innovative regions are located on the axis between London and Rome, in the Benelux countries, Germany, Northern Italy and in some Spanish and Scandinavian regions. It is very interesting that EPO patent applications and university patents cluster in the same countries and concentrate in the center of Europe but highest value regions in both variables do not coincide.

\section{The role of institutional and regional factors in university patenting in Europe}

In this section we provide an exploratory-type regression analysis on the role of institutional and regional factors on the probability of university patenting. Tables 4 and 5 depicts binary Probit regression results. Variable selection for the models followed the threestep procedure as described in the previous section. Availability of university characteristics from the EUMIDA extended database and regionalization of EUMIDA data to the NUTS 3 level make these first cut regressions possible. Large number of missing values in the data set and correlations among some of the explanatory variables urge us to follow a very careful step-by-step regression approach to finally distill the model that reflects institutional-regional interrelations in the most reliable manner.

Models in Table 4 focus on institutional-level factors in university patenting. Research activity is certainly the most relevant input in university patenting. We experimented with two measures of research intensity that is $R \& D$ expenditures and number of doctoral degrees awarded by the institution. The drawback of the R\&D data (questionable representativeness resulting from frequently missing values) has already been demonstrated in the previous section. In Table 6 it became clear that the size measure (academic staff) and R\&D expenditures are highly correlated. Thus small number of observations and potential multicollinearity advice us to drop the R\&D expenditures variable from the model. The other proxy for research intensity, number of doctorate degrees awarded also correlates with academic staff and as shown in Model 5 even with the share of ISCED 6 international students' share. Loosing significance and the strong drop in parameter value suggest the 
presence of multicollinearity in Model 5. Due to correlations from Model 6 we consider the number of academic staff as a proxy for both institution size and research intensity. Share of ISCED 6 students and share of third party funds are variables to be selected after a longer procedure of trials of alternative measures of international embeddedness and external fudning.

Models 7 to 11 in Table 4 show that research intensity and size (measured by academic staff), international embeddedness and third party funding are positively associated with the probability of university patenting. The models also suggest that institutions focusing more intensely on education are most probably not productive in patenting and that patenting probability is not affected by the age of a university. However, specialization of academic staff in natural science, engineering and medical fields increase patenting probability such that the general quality of an institution. The last two models in Table 4 show similar behavior. However, Model 11 in Table 4 (Model 1 in Table 5) is selected as a base for regional extension in Table 5 because of its significantly larger institutional coverage (893 vs. 760) ${ }^{7}$.

Table 5 presents the results of the Probit regressions when regional variables are also included in the model. The literature is somewhat ambiguous as to the impact of agglomeration on academic entrepreneurship. However, the impact of regional factors on university patenting (a special form of academic entrepreneurship) has not been studied much in the literature. So our findings based on a large data set covering many of the European institutes certainly bring important information to this specific field of study. Descriptive analyses in the previous section indicate that the regional impact on university patenting will most probably be very limited. Regression results in Table 5 indicate that regional size, concentration of public research, agglomeration of regional business services and regional technological output are all negatively associated with the probability of university patenting. The strong negative effects are certainly surprising results. This finding is strongly reinforced by Model 6 in Table 5 where a summary measure of the development of the regional innovation system (a dummy for high innovation regions) is included in the regression. Model 8 presents the marginal effects in the final regression (Model 6). As suggested increasing international embeddedness and external funding have some important potentials for universities to expand their patenting activities.

\footnotetext{
${ }^{7}$ Note that the regional extension was carried out with the base of Model 10 as well and the findings are essentially the same as the ones shown in Table 5. (Regression results are available upon request.)
} 
Table 4 Binary Probit ML Estimation Results:

The Role of Institutional Factors in European University Patenting ${ }^{\mathrm{a}}$

\begin{tabular}{|c|c|c|c|c|c|c|c|c|c|c|c|}
\hline Model & $(1)$ & $(2)$ & (3) & (4) & $(5)$ & (6) & $(7)$ & $(8)$ & (9) & $(10)$ & $(11)$ \\
\hline $\begin{array}{l}\text { Constant } \\
\text { R\&D expenditures, } 2008 \\
\text { Number of Doctoral Degrees, } \\
2008\end{array}$ & $\begin{array}{c}-0.8270^{* * * *} \\
(0.0684)^{\mathrm{b}} \\
4.96 \mathrm{E}-09^{* * *} * \\
(1.12 \mathrm{E}-09)\end{array}$ & $\begin{array}{c}-1.7433 * * * \\
(0.1172) \\
-2.79 \mathrm{E}-09 * \\
(1.59 \mathrm{E}-09)\end{array}$ & $\begin{array}{c}-1.5481 * * * \\
(0.0603) \\
\\
0.0061 * * * \\
(0.0004)\end{array}$ & $\begin{array}{c}-18450 * * * \\
(0.0799) \\
0.0022 * * * \\
(0.0006)\end{array}$ & $\begin{array}{c}-2.2568 * * * \\
(0.1103) \\
\\
\\
0.0007 \\
(0.0007)\end{array}$ & $\begin{array}{l}-2.3117 * * * * \\
(0.1056)\end{array}$ & $\begin{array}{c}-2.3713 * * * \\
(0.1404)\end{array}$ & $\begin{array}{c}-2.3528 * * * \\
(0.1694)\end{array}$ & $\begin{array}{l}-2.3724 * * * * \\
(0.1435)\end{array}$ & $\begin{array}{l}-2.5924 * * * \\
(0.1818)\end{array}$ & $\begin{array}{c}2.2963 * * * \\
(0.1437)\end{array}$ \\
\hline Academic Staff, 2008 & & $\begin{array}{c}0.0011 * * * \\
(0.0001)\end{array}$ & & $\begin{array}{c}0.0008^{* * *} \\
(0.0001)\end{array}$ & $\begin{array}{l}0.0009^{* * *} \\
(0.0001)\end{array}$ & $\begin{array}{l}0.0010 * * * \\
(6.62 \mathrm{E}-05)\end{array}$ & $\begin{array}{l}0.0010 * * * \\
(7.31 \mathrm{E}-05)\end{array}$ & $\begin{array}{l}0.0010 * * * \\
(7.84 \mathrm{E}-05)\end{array}$ & $\begin{array}{l}0.0010 * * * \\
(8.34 \mathrm{E}-05)\end{array}$ & $\begin{array}{l}0.0009 * * * \\
(7.74 \mathrm{E}-05)\end{array}$ & $\begin{array}{l}0.0009 * * * \\
(9.23 \mathrm{E}-05)\end{array}$ \\
\hline $\begin{array}{l}\text { Share of ISCED } 6 \text { International } \\
\text { Students in Total ISCED } 6 \\
\text { Students, } 2008^{\mathrm{c}}\end{array}$ & & & & & $\begin{array}{c}2.6709^{* * * *} \\
(0.3132)\end{array}$ & $\begin{array}{c}2.8421 * * * \\
(0.3026)\end{array}$ & $\begin{array}{c}2.1896 * * * \\
(0.3304)\end{array}$ & $\begin{array}{c}2.1675^{* * *} \\
(0.3434)\end{array}$ & $\begin{array}{c}2.1783 * * * \\
(0.3334)\end{array}$ & $\begin{array}{c}2.0586^{* * * *} \\
(0.3506)\end{array}$ & $\begin{array}{c}2.0717 * * * * \\
(0.3362)\end{array}$ \\
\hline $\begin{array}{l}\text { Share of 3rd Party Funds in } \\
\text { Total Income, } 2008^{\mathrm{d}}\end{array}$ & & & & & & & $\begin{array}{c}0.7609 * * * \\
(0.2715)\end{array}$ & $\begin{array}{c}0.8069^{* * *} \\
(0.2775)\end{array}$ & $\begin{array}{c}0.7584 * * * \\
(0.2731)\end{array}$ & $\begin{array}{l}0.5437 * \\
(0.2856)\end{array}$ & $\begin{array}{c}0.6533 * * \\
(0.2778)\end{array}$ \\
\hline $\begin{array}{l}\text { Share of Tuition Fees in Total } \\
\text { Income }\end{array}$ & & & & & & & & $\begin{array}{l}-0.2301 \\
(0.4105)\end{array}$ & & & \\
\hline $\begin{array}{l}\text { Age of the Institution, } 2008 \\
\text { Share of Academic Staff in } \\
\text { Natural Sciences, Engineering } \\
\text { and Medical Sciences in Total } \\
\text { Academic Staff, } 2008\end{array}$ & & & & & & & & & $\begin{array}{l}4.09 \mathrm{E}-05 \\
(0.0004)\end{array}$ & $\begin{array}{c}1.6835 * * * \\
(0.3917)\end{array}$ & \\
\hline ARWU Top 500, 2008 & & & & & & & & & & & $\begin{array}{c}0.3569^{* *} \\
(0.1784) \\
\end{array}$ \\
\hline McFadden R-squared & 0.05 & 0.29 & 0.32 & 0.37 & 0.43 & 0.43 & 0.43 & 0.44 & 0.43 & 0.44 & 0.43 \\
\hline Number of observations & 535 & 496 & 1294 & 1225 & 1139 & 1187 & 893 & 892 & 872 & 760 & 893 \\
\hline
\end{tabular}

Source: authors' own construction

a. The dependent variable takes 1 if at least 1 patent is assigned to the university in 2006-2008.

b. Estimated standard errors are in parentheses; $* * *$ indicates significance at $\mathrm{p}<0.01$; $* *$ indicates significance at $\mathrm{p}<0.05 ; *$ indicates $\mathrm{p}<0.1$.

c. This variable was selected as a result of systematic regression runs accounting for the impact of international embededdness by different indicators (see Table A1) in the same econometric model (Model 5).

$\mathrm{d}$. This variable was selected as a result of systematic regression runs accounting for the impact of external connectivity by different indicators (see Table A1) in the same econometric model (Model 7). 
Table 5 Binary Probit ML Estimation Results:

The Role of Institutional and Regional Factors in European University Patenting ${ }^{\mathrm{a}}$

\begin{tabular}{|c|c|c|c|c|c|c|c|c|}
\hline Model & (1)* & (2) & (3) & (4) & (5) & (6) & (7) & $\begin{array}{l}(8) \\
\text { Marginal Effects in } \\
\text { Model (6) }\end{array}$ \\
\hline Constant & $\begin{array}{l}-2.2963^{* * * *} \\
(0.1437)^{\mathrm{b}}\end{array}$ & $\begin{array}{c}-2.2484 * * * \\
(0.1460)\end{array}$ & $\begin{array}{c}-2.2567 * * * \\
(0.1449)\end{array}$ & $\begin{array}{c}-2.2351 * * * \\
(0.2698)\end{array}$ & $\begin{array}{c}-2.1420 * * * \\
(0.1598)\end{array}$ & $\begin{array}{c}-2.2409 * * * \\
(0.1493)\end{array}$ & $\begin{array}{c}-2.0193 * * * \\
(0.3255)\end{array}$ & $\begin{array}{c}-0.4632 * * * \\
(0.1493)\end{array}$ \\
\hline Academic Staff, 2008 & $\begin{array}{l}0.0009 * * * \\
(9.23 \mathrm{E}-05)\end{array}$ & $\begin{array}{l}0.0009 * * * \\
(9.30 \mathrm{E}-05)\end{array}$ & $\begin{array}{l}0.0009 * * * \\
(9.29 \mathrm{E}-05)\end{array}$ & $\begin{array}{c}0.0006^{* * *} \\
(0.0002)\end{array}$ & $\begin{array}{l}0.0009 * * * \\
(9.73 \mathrm{E}-05)\end{array}$ & $\begin{array}{l}0.0009 * * * \\
(9.31 \mathrm{E}-05)\end{array}$ & $\begin{array}{c}0.0006^{* * * *} \\
(0.0002)\end{array}$ & $\begin{array}{l}0.0002 * * * \\
(9.31 \mathrm{E}-05)\end{array}$ \\
\hline Share of ISCED 6 International & $2.0717^{* * *}$ & $2.2236^{* * *}$ & $2.2843^{* * *}$ & $3.2235 * * *$ & $2.0125^{* * *}$ & $2.0988^{* * *}$ & $3.4499^{* * *}$ & $0.4338 * * *$ \\
\hline $\begin{array}{l}\text { Students in Total ISCED } 6 \\
\text { Students, } 2008^{c}\end{array}$ & $(0.3362)$ & $(0.3491)$ & $(0.3534)$ & $(0.6066)$ & $(0.3552)$ & $(0.3512)$ & $(0.7126)$ & $(0.3512)$ \\
\hline Share of 3rd Party Funds in & $0.6533 * *$ & $0.6027^{* *} *$ & $0.6482 * *$ & -0.3113 & $0.6068 * *$ & $0.8479 * * *$ & 0.0293 & $0.1753^{* * *}$ \\
\hline Total Income, 2008 & $(0.2778)$ & $(0.2801)$ & $(0.2799)$ & $(0.9514)$ & $(0.2938)$ & $(0.2874)$ & $(0.9790)$ & $(0.2874)$ \\
\hline ARWU Top 500, 2008 & $\begin{array}{l}0.3569^{* *} \\
(0.1784)\end{array}$ & $\begin{array}{l}0.3376^{*} \\
(0.1791)\end{array}$ & $\begin{array}{l}0.3481^{*} \\
(0.1788)\end{array}$ & $\begin{array}{l}0.5516^{*} \\
(0.3151)\end{array}$ & $\begin{array}{c}0.3071 \\
(0.1901)\end{array}$ & $\begin{array}{c}0.4164 * * \\
(0.1839)\end{array}$ & $\begin{array}{l}0.7649 * * \\
(0.3870)\end{array}$ & $\begin{array}{l}0.0861 * * \\
(0.1839)\end{array}$ \\
\hline Regional Population, 2008 & & $\begin{array}{l}-6.05 \mathrm{E}-05^{*} \\
(3.55 \mathrm{E}-05)\end{array}$ & & & & & $\begin{array}{l}-0.0003 \\
(0.0004)\end{array}$ & \\
\hline $\begin{array}{l}\text { Doctoral Degrees Awarded in } \\
\text { the Region' }, 2008\end{array}$ & & & $\begin{array}{l}-0.0002 * * \\
(9.58 \mathrm{E}-05)\end{array}$ & & & & $\begin{array}{l}-0.0007 \\
(0.0007)\end{array}$ & \\
\hline $\begin{array}{l}\text { Regional Business Services } \\
\text { Employment: NACE J, K, } M^{\mathrm{d}} \text {, } \\
2008\end{array}$ & & & & $\begin{array}{l}-0.0006^{*} \\
(0.0003)\end{array}$ & & & $\begin{array}{l}0.0036 \\
(0.0032)\end{array}$ & \\
\hline $\begin{array}{l}\text { EPO Patentt Applications from } \\
\text { the Region, } 2008\end{array}$ & & & & & $\begin{array}{c}-0.0010^{*} \\
(0.0006)\end{array}$ & & $\begin{array}{l}-0.0022 \\
(0.0016)\end{array}$ & \\
\hline High Innovation Region ${ }^{\mathrm{e}}, 2006$ & & & & & & $\begin{array}{c}-0.4818 * * * \\
(0.1629)\end{array}$ & $\begin{array}{c}-1.2524 * * * \\
(0.3572)\end{array}$ & $\begin{array}{c}-0.0996 * * * \\
(0.1629)\end{array}$ \\
\hline McFadden R-squared & 0.43 & 0.44 & 0.44 & 0.39 & 0.41 & 0.44 & 0.42 & 0.44 \\
\hline Number of observations & 893 & 893 & 893 & 336 & 810 & 862 & 299 & 862 \\
\hline
\end{tabular}

Source: authors' own construction

a. The dependent variable takes 1 if at least 1 patent is assigned to the university in 2006-2008.

b. Estimated standard errors are in parentheses; $* * *$ indicates significance at $\mathrm{p}<0.01$; $* *$ indicates significance at $\mathrm{p}<0.05$; $*$ indicates $\mathrm{p}<0.1$.

c. Regional sum without counting the value of the respective institution.

d. J: Information and communication; K: Finance and insurance; M: Professional, scientific and technical activities, administrative and support services.

e. Dummy variable: it takes the value of 1 if the region is specified as „High innovation region” in the European Regional Innovation Scoreboard (Hollanders et al. 2009).

* The last two models in Table 4 show similar behavior. However, Model 11 in Table 4 (Model 1 in Table 5) is selected as a base for regional extension because of its significantly larger

institutional coverage ( 893 vs. 760 ). Note that the regional extension was carried out with the base of Model 10 as well and the findings are essentially the same as the ones shown in Table 5 .

(Regression results are available upon request.) 


\section{Conclusion}

In this paper we carried out a first cut spatial exploratory study on EUMIDA data with a large coverage of European research oriented universities (about two-third of research active universities are included even in the final regression sample). An important additional novelty of our study is that NUTS3 level aggregation of data is applied contrary to the usually utilized NUTS 2 information.

Most of the institutional factors (university size, research intensity, external funding, international embeddedness and university quality) stand in a positive association with university patenting. This reinforces previous findings in the literature by studies usually operating with significantly less coverage of higher education institutions.

The most surprising results are related to the role of regional factors in university patenting. Our final results suggest that the role of those regional factors that are usually found important for university technology transfer (regional size, concentration of public research, agglomeration of regional business services, regional technological output and the development of the regional innovation system) are all negatively associated with the probability of university patenting. These results suggest that the regional innovation environment is not only marginally important for university patenting (which have already been suspected by some studies in the literature) but its impact is even negative: universities located in regions with less developed innovation systems seem to have a higher chance to patent than otherwise. This is an important and new observation.

The negligible role of regional factors in university patenting in our study resembles very much to findings on publication behavior where the agglomeration of regional innovation factors' impact is not observed either (Varga, Pontikakis, Chorafakis 2013, Sebestyén, Varga 2013). Thus it seems that university patenting is driven by institutional and regional factors similar to those that drive publication behavior. It is a somewhat strange result considering an activity (patenting) that is supposed to be related to the industrial world. However, this result might be related to findings of those studies where limited industrial relevance of a significant share of university patents is suggested.

There are several constraints of this study. The first one is that only the impacts on the probability of patenting are studied with no distinction being made with respect to the intensity of patenting. This choice ruled out the possibility to examine more closely those institutions that seem to be outliers in many respects. When we made the decision to focus on the presence of patents but not on their quality we might also ruled out to study some of the 
potentially important differences among higher quality university patent producing institutions and the other institutions developing only medium or low quality patents. Considering the aspects of quality might put the impact of the regional innovation environment in a different perspective as well. We leave these research possibilities open for further attempts.

\section{References}

Acosta, M., - Coronado, D. - Martínez, M. Á. (2012): Spatial differences in the quality of university patenting: Do regions matter? Research Policy, 41, pp. 692-703.

Academic Ranking of World Universities (2008): Academic Ranking of World Universities - 2008. Source: http://www.arwu.org/ARWU2008.jsp Accessed: 1 June 2012.

AUTM (2011): US and Canadian Licensing Activity Surveys - quantitative data and real-world examples about licensing activities at US and Canadian universities, hospitals and research institutions. Association of University Technology Managers. East Lansing.

Azagra-Caro, J. M. - de Lucio, I. F. - Gracia, A. G. (2003): University patents: output and input indicators ... of what? Research Evaluation, 12, pp. 5-16.

Azagra-Caro, J. M. - Pontikakis, D. - Varga A. (2013): Absorptive capacity and the delocalisation of university-industry interaction. Evidence from participations in the EU's Sixth Framework Programme for Research. European Planning Studies (forthcoming).

Bonaccorsi, A. - Brandt, T. - De Filippo, D. - Lepori, B. - Molinari, F. - Niederl, A. - Schmoch, U. - Schubert, T. - Slipersaeter, S. (2010): Feasibility Study for Creating European University Data Collection. Final Study Report. European Commission, Research Directorate - General, Directorate C - European Research Area, Universities and Researches. Source: http://www.google.hu/url?sa=t\&rct=j\&q=\&esrc=s\&source=web\&cd=2\&cad=rja\&ved=0CCYQFjAB \&ur $\mathrm{l}=\mathrm{http} \% 3 \mathrm{~A} \% 2 \mathrm{~F} \% 2 \mathrm{Fec}$.europa.eu\%2Fresearch $\% 2 \mathrm{Fera} \% 2 \mathrm{Fdocs} \% 2 \mathrm{Fen} \% 2 \mathrm{Feumida}$-finalreport.pdf\&ei=hBVDUKTWNcXctAbA04CIAQ\&usg=AFQjCNH9mnZ1Brx1qeCc1nBNTT3mwuzB4w \&sig2=Ya5ygLu7k4dg_mbgaG4qIg Accessed: 31 August 2012.

Carlsson, B. - Fridh, A. (2002): Technology transfer in United States universities: a survey and statistical analysis. Journal of Evolutionary Economics, 12, pp. 199-232.

Coupé, T. (2003): Science is golden: academic R\&D and university patents. Journal of Technology Transfer, 28, pp. 31-46.

Erdős K. - Varga A. (2012): The academic entrepreneur: myth or reality for increased regional growth in Europe? In van Geenhuizen, M. - Nijkamp, P. (eds): Creative Knowledge Cities. Edward Elgar, Cheltenham, UK and Northamptom, MA, US, pp. 157-181.

Feldman, M. (1994): The University and Economic Development: The Case of Johns Hopkins University and Baltimore. Economic Development Quarterly, 8, pp. 67-76.

Friedman, J. - J. Silberman (2003): University technology transfer: do incentives, management and location matter? Journal of Technology Transfer, 28, pp. 17-30.

Goldstein, H. (2002): Universities as Regional Growth Engines: The Case of the Research Triangle of North Carolina. In Varga A. - Szerb L. (eds): Innovation, Entrepreneurship and Regional Economic Development: International Experiences and Hungarian Challenges. University of Pécs Press, Pécs, pp. 208-231.

Giuliani, E. - Arza, V. (2009): What drives the formation of valuable university-industry linkages? Insights from the wine industry. Research Policy, 38, pp. 906-921.

Gulbrandsen, M. - Slipersæter, S. (2007): The third mission and the entrepreneurial university model. In Bonaccorsi, A. (ed.): Universities and Strategic Knowledge Creation: Specialization and Performance In Europe. Edward Elgar, Cheltenham, UK and Northampton, MA, US, pp. 112143.

Hollanders, H. - Tarantola, S. - Loschky, A. (2009): Regional Innovation Scoreboard (RIS) 2009. Pro Inno Europe Paper, 14, Entreprise and Industry Magazine, Brussels. Source: http://www.proinno-europe.eu/page/regional-innovation-scoreboard 
Koo, J. (2007): Determinants of Localized Technology Spillovers: Role of Regional and Industrial Attributes. Regional Studies, 41, pp. 995-1011.

Lach, S. - Schankerman, M. (2004): Royalty sharing and technology licensing in universities. Journal of the European Economic Association, 2, pp. 252-264.

Landry, R. -. Amara, N. - Ouimet, M. (2007): Determinants of knowledge transfer: evidence from Canadian university researchers in natural sciences and engineering. Journal of Technology Transfer, 32, pp. 561-592.

Louis, K. S. - Blumenthal, D. - Gluck, M. E. - Stoto, M. A. (1989): Entrepreneurs in Academe: An Exploration of Behaviors among Life Scientists. Administrative Science Quarterly, 34, pp. 110 131.

NSF (2010): NSF Survey of Research and Development Expenditures at Universities and Colleges/Higher Education Research and Development. National Science Foundation, Arlington.

Pike, A. - Rodríguez-Pose, A. - Tomaney, J. (eds) (2011): Handbook of Local and Regional Development. Routledge, London, UK and New York, US.

Ponomariov, B. L. (2008): Effects of university characteristics on scientists' interactions with the private sector: an exploratory assessment. Journal of Technology Transfer, 33, pp. 485-503.

Renault, C. (2006): Academic Capitalism and University Incentives for Faculty Entrepreneurship. Journal of Technology Transfer, 31, 2, pp. 227-239.

Rogers, E. M. - Yin, J.- Hoffmann, J. (2000): Assessing the effectiveness of technology transfer offices at US research universities. The Journal of the Association of University Technology Managers, 12, pp. 47-80.

Saragossi, S. - Van Pottelsberghe de la Potterie, B. (2003): What patent data reveal about universities: the case of Belgium. Journal of Technology Transfer, 28, pp. 47-51.

Saxenian, A. (1994): Regional advantage: culture and competition in Silicon Valley and Route 128. Harvard University Press, Cambridge, US.

Schartinger, D., - Rammer, C. - Fischer, M. - Fršhlich, J. (2002): Knowledge interactions between universities and industry in Austria: sectoral patterns and determinants. Research Policy, 31, pp. 303-328.

Sebestyén T. - Varga A (2013): Research Productivity and the Quality of Interregional Knowledge Networks. Annals of Regional Science (forthcoming).

Siegel, D. S. - Waldmann, D. A. - Link, A. N. (2003): Assessing the impact of organizational practices on the productivity of university technology transfer offices: an exploratory study. Research Policy, 32, pp. 27-48.

Van Looy, B. - Ranga, M. - Callaert, J. - Debackere, K. - Zimmermann, E. (2004): Combining entrepreneurial and scientific performance in academia: towards a compounded and reciprocal Matthew-effect? Research Policy, 33, pp. 425-441.

Varga A. (1998): University Research and Regional Innovation: A Spatial Econometric Analysis of Academic Technology Transfers. Kluwer Academic Publishers, Boston.

Varga A. (2000): Local academic knowledge spillovers and the concentration of economic activity. Journal of Regional Science, 40, pp. 289-309.

Varga A. (ed.) (2009): Universities, Knowledge Transfer and Regional Development: Geography, Entrepreneurship and Policy. Edward Elgar. Cheltenham, UK and Northampton, MA, US.

Varga A. - Anselin, L. - Acs Z. (2005): Regional innovation in the US over space and time. In Maier, G. - Sedlace, S. (eds): Spillovers and Innovation: City, Environment, and the Economy. Interdisciplinary Studies in Economics and Management. Springer, Wien, Austria and New York, US, pp. 93-104.

Varga A. - Pontikakis, D. - Chorafakis, G. (2012): Metropolitan Edison and cosmopolitan Pasteur? Agglomeration and interregional research network effects on European R\&D productivity. Journal of Economic Geography (forthcoming).

Wicksteed, W. - Autio, E. - Doel C. - Garnsey E. - Green C. - Peters K. (2000): The Cambridge Phenomenon Revisited. Wicksteed, Cambridge, UK, Segal Quince. 
Appendix 1 The set of potential institutional variables

\begin{tabular}{|c|c|c|c|c|c|c|}
\hline \multirow{3}{*}{$\begin{array}{l}\text { Regional } \\
\text { characteristic }\end{array}$} & \multirow{3}{*}{ Proxy variable } & \multirow{3}{*}{ Data source } & \multirow{2}{*}{\multicolumn{4}{|c|}{$\begin{array}{c}\text { Probit model with one explanatory variable } \\
\text { Dependent variable: Binary (it equals } 1 \text { if the } \\
\text { institution owns any patent with priority year 2006, } \\
2007 \text { or } 2008 \text { and } 0 \text { otherwise) }\end{array}$}} \\
\hline & & & & & & \\
\hline & & & $\begin{array}{c}\text { Parameter } \\
\text { sign }\end{array}$ & $\begin{array}{c}\text { Parameter } \\
\text { significance at } \\
\mathbf{p}<0.1\end{array}$ & $\begin{array}{l}\text { McFadden } \\
\text { R-squared }\end{array}$ & $\begin{array}{c}\text { Observation } \\
\text { number }\end{array}$ \\
\hline RESEARCH & Number of Doctoral Degrees, 2008 & EUMIDA (Extended) & + & $\mathrm{S}$ & 0.31 & 1294 \\
\hline INTENSITY & R\&D Expenditures in EUR, 2008 & EUMIDA (Extended) & + & $\mathrm{s}$ & 0.04 & 535 \\
\hline \multirow{6}{*}{$\begin{array}{l}\text { SIZE OF THE } \\
\text { INSTITUTION }\end{array}$} & Total Staff, 2008 & EUMIDA (Extended) & + & $\mathrm{S}$ & 0.33 & 1227 \\
\hline & Academic Staff, 2008 & EUMIDA (Extended) & + & $\mathrm{s}$ & 0.35 & 1276 \\
\hline & Total Students ISCED 5, 2008 & EUMIDA (Extended) & + & $\mathrm{s}$ & 0.12 & 1349 \\
\hline & Total Students ISCED 6, 2008 & EUMIDA (Extended) & + & $\mathrm{s}$ & 0.23 & 1347 \\
\hline & Total Expenditures in EUR, 2008 & EUMIDA (Extended) & + & $\mathrm{s}$ & 0.12 & 1059 \\
\hline & Core Funding in EUR, 2008 & EUMIDA (Extended) & + & not & 0.00 & 699 \\
\hline \multirow{3}{*}{$\begin{array}{l}\text { INTERNATIONAL } \\
\text { EMBEDDEDNESS }\end{array}$} & Foreign Academic Staff, 2008 & EUMIDA (Extended) & + & $\mathrm{S}$ & 0.10 & 647 \\
\hline & $\begin{array}{l}\text { Share of ISCED } 6 \text { International Students in } \\
\text { Total ISCED } 6 \text { Students, } 2008\end{array}$ & calculated & + & $\mathrm{s}$ & 0.07 & 769 \\
\hline & $\begin{array}{l}\text { Share of International Degrees (Doctorate) in } \\
\text { Total Degrees (Doctorate) , } 2008\end{array}$ & calculated & + & $\mathrm{s}$ & 0.03 & 533 \\
\hline \multirow{4}{*}{ EXTERNAL FUNDING } & R\&D Funding Private Sector in EUR, 2008 & EUMIDA (Extended) & + & $\mathrm{S}$ & 0.03 & 841 \\
\hline & $\begin{array}{l}\text { Share of R\&D Funding Private Sector in Total } \\
\text { Income, } 2008\end{array}$ & calculated & - & not & 0.00 & 449 \\
\hline & 3rd Party Funding in EUR, 2008 & EUMIDA (Extended) & + & not & NA & 1001 \\
\hline & Share of 3rd Party Funds in Total Income, 2008 & calculated & + & $\mathrm{s}$ & 0.01 & 1000 \\
\hline $\begin{array}{l}\text { EDUCATION } \\
\text { SIGNIFICANCE }\end{array}$ & Share of Tuition Fees in Total Income, 2008 & calculated & - & $\mathrm{s}$ & 0.01 & 979 \\
\hline $\begin{array}{l}\text { AGE OF THE } \\
\text { INSTITUTION }\end{array}$ & Age of the Institution in 2008 & EUMIDA (Core) & + & $\mathrm{S}$ & 0.11 & 1334 \\
\hline \multirow{4}{*}{$\begin{array}{l}\text { SCIENTIFIC } \\
\text { SPECIALIZATION }\end{array}$} & Share of Staff in Natural Science, 2008s & calculated & + & $\mathrm{S}$ & 0.15 & 822 \\
\hline & Share of Staff in Engineering Technology, 2008 & calculated & + & not & 0.00 & 822 \\
\hline & Share of Staff in Medical Sciences, 2008 & calculated & + & S & 0.02 & 822 \\
\hline & $\begin{array}{l}\text { Share of Academic Staff in Natural Sciences, } \\
\text { Engineering and Medical Sciences in Total } \\
\text { Academic Staff, } 2008\end{array}$ & calculated & + & $\mathrm{s}$ & 0.09 & 822 \\
\hline \multirow{3}{*}{$\begin{array}{l}\text { UNIVERSITY } \\
\text { PRESTIGE }\end{array}$} & ARWU Top 100, 2008 & $\begin{array}{l}\text { Academic Rankings } \\
\text { of World }\end{array}$ & + & $\mathrm{S}$ & 0.04 & 1364 \\
\hline & & Universities & & & & \\
\hline & ARWU Top 500, 2008 & $\begin{array}{l}\text { Academic Rankings } \\
\text { of World } \\
\text { Universities* }\end{array}$ & + & $\mathrm{s}$ & 0.28 & 1364 \\
\hline
\end{tabular}

Source: own construction

Note: *ARWU (2008) 
Appendix 2 The set of potential regional variables

\begin{tabular}{|c|c|c|c|c|c|c|}
\hline \multirow{3}{*}{$\begin{array}{l}\text { Regional } \\
\text { characteristic }\end{array}$} & \multirow{3}{*}{ Proxy variable } & \multirow{3}{*}{ Data source } & \multicolumn{4}{|c|}{ Probit model with one explanatory variable } \\
\hline & & & \multicolumn{4}{|c|}{$\begin{array}{l}\text { Dependent variable: Binary (it equals } 1 \text { if the } \\
\text { institution owns any patent with priority year } \\
\quad 2006,2007 \text { or } 2008 \text { and } 0 \text { otherwise) }\end{array}$} \\
\hline & & & $\begin{array}{l}\text { Paramet } \\
\text { er sign }\end{array}$ & $\begin{array}{l}\text { Parameter } \\
\text { significanc } \\
\text { e at p }< \\
0.1\end{array}$ & $\begin{array}{l}\text { McFadde } \\
\text { n R- } \\
\text { squared }\end{array}$ & $\begin{array}{l}\text { Observatio } \\
\text { n number }\end{array}$ \\
\hline \multirow{3}{*}{ REGIONAL SIZE } & $\begin{array}{l}\text { Regional Population - Annual Average Population in the } \\
\text { Region, } 2008 \text { (1000) }\end{array}$ & Eurostat & + & S & 0.00 & 1364 \\
\hline & Employment 2008 - Total - All NACE Activities (1000) & Eurostat & + & not & 0.00 & 1159 \\
\hline & GDP at Current Market Prices 2008 (Millions of PPS) & Eurostat & + & not & 0.00 & 1128 \\
\hline $\begin{array}{l}\text { REGIONAL } \\
\text { UNIVERSITY } \\
\text { RESEARCH } \\
\text { INTENSITY }\end{array}$ & Doctoral Degrees Awarded in the Region, 2008 & $\begin{array}{l}\text { EUMIDA (Core) - } \\
\text { aggregated to } \\
\text { NUTS } 3 \text { level }\end{array}$ & + & S & 0.00 & 1364 \\
\hline \multirow{12}{*}{$\begin{array}{l}\text { INDUSTRIAL } \\
\text { SPECIALIZATION }\end{array}$} & Employment 2008 - Agriculture, Forestry and Fishing & Eurostat & + & $\mathrm{S}$ & 0.01 & 746 \\
\hline & Employment 2008 - Industry (except Construction) & Eurostat & + & not & 0.00 & 764 \\
\hline & Employment 2008 - Manufacturing & Eurostat & + & not & 0.00 & 763 \\
\hline & Employment 2008 - Construction & Eurostat & + & S & 0.00 & 764 \\
\hline & $\begin{array}{l}\text { Employment } 2008 \text { - Wholesale and Retail Trade, Transport, } \\
\text { Accommodation and Food Service Activities }\end{array}$ & Eurostat & + & S & 0.00 & 695 \\
\hline & Employment 2008 - Information and Communication & Eurostat & + & not & 0.00 & 648 \\
\hline & Employment 2008 - Financial and Insurance Activities & Eurostat & + & $S$ & 0.01 & 695 \\
\hline & Employment 2008 - Real estate Activities & Eurostat & + & not & 0.00 & 648 \\
\hline & $\begin{array}{l}\text { Employment } 2008 \text { - Professional, Scientific and Technical } \\
\text { Activities; Administrative and Support Service Activities }\end{array}$ & Eurostat & + & not & 0.00 & 648 \\
\hline & $\begin{array}{l}\text { Employment } 2008 \text { - Regional Business Services (Information } \\
\text { and Communication; Financial and Insurance Activities; } \\
\text { Professional, Scientific and Technical Activities; } \\
\text { Administrative and Support Service Activities) }\end{array}$ & calculated & + & not & 0.00 & 648 \\
\hline & $\begin{array}{l}\text { Employment } 2008 \text { - Public Administration, Defence, } \\
\text { Education, Human Health and Social Work Activities }\end{array}$ & Eurostat & + & S & 0.00 & 695 \\
\hline & $\begin{array}{l}\text { Employment } 2008 \text { - Arts, Entertainment and Recreation; Other } \\
\text { Service Activities; Activities of Household and Extra- } \\
\text { Territorial Organizations and Bodies }\end{array}$ & Eurostat & + & not & 0.00 & 648 \\
\hline \multirow[b]{2}{*}{$\begin{array}{l}\text { REGIONAL } \\
\text { INNOVATION }\end{array}$} & EPO Patent Applications from the Region, 2008 & Eurostat & - & $\mathrm{S}$ & 0.01 & 1231 \\
\hline & High Innovation Region, 2006 & $\begin{array}{l}\text { European Regional } \\
\text { Innovation } \\
\text { Scoreboard* }\end{array}$ & - & not & 0.00 & 1328 \\
\hline
\end{tabular}

Source: own construction

Note: *Hollanders et al. (2009) 